\title{
Bosnia needs an assertive Europe 1
}

Dans la plupart des pays convertis récemment à la démocratie ou, plus exactement, où les méthodes de la démocratie occidentale sont importées sans qu'il y ait préparation authentique dans le pays, il y a pseudo-démocratie ou démocratie corrompue, parce qu'il n'y a pas réellement cette tension créatrice entre la puissance sociale et le pouvoir politique, mais manipulation des institutions pseudo-démocratiques par les détenteurs du pouvoir social. Dans ce caslà, il n'y a pas possibilité, pour les représentants des nouvelles classes sociales, d'arriver au pouvoir. Alors, c'est la revolution. ${ }^{2}$

Raymond Aron (1997) Introduction à la philosophie politique Paris: Fallois, p. 108.

When it comes to Bosnia's complex and often contradictory post-war history, those who claim to 'know' what's good for the torn country, are - more often than not wrong.

The brief episode of March 2014, euphemistically termed the 'Bosnian spring', has not been followed by a democratic summer; while the autumn elections will bring more of the same: the crisis that has been eating away at the country for over ten years knows no seasons. The social upheavals in Tuzla, Sarajevo and other Bosnian towns, of a disillusioned and desperate generation, have generated worldwide attention. It remains to be seen to what effect.

By a quirk of fate, the return of the Yugoslav self-management tradition is outperforming both the nationalist parties and the many western 'civil society' programmes which have given rise to an NGO culture at times more self-referential than interested in the common good. In spite of the shock wave that had paralysed a spent political class, a truly citizen-centred politics, and a concern for bread-and-butter issues as expressed in the brilliant slogan gladni smo na sva tri jezika ('We are hungry in three languages'), is still not in sight.

We should better understand what is today being heralded as a new social movement were we to look back at the April 1992 pacifist movement, or to the wartime Citizens' Forum in Tuzla which united some ten thousand citizens in proactive solidarity. ${ }^{3}$ This

1 An earlier version of this article was published by openDemocracy as 'The undeluded going astray in Bosnia' on 24 February 2014.

2 Editor's Note: In unofficial translation, this passage reads as follows: 'In most countries which have recently converted to democracy or, more precisely, where western democratic methods have been imported without proper preparation within the country, there we find a pseudodemocracy, or a corrupted democracy, because there is no real creative tension between the social power and the political power, only the manipulation of pseudo-democratic institutions by the holders of social power. In such a case, there is no possibility for the representatives of new social classes to come to power. At which point, there is revolution.'.

3 For a broader and detailed discussion on (post-)Yugoslav anti-war activism, see Bojan Bilić (2012) We Were Grasping for Air: [Post-] Yugoslav Anti-War Activism and Its Legacy BadenBaden: Nomos; and Bojan Bilić and Vesna Janković (Eds.) (2012) Resisting the Evil: [Post-]Yugoslav Anti-War Contention Baden-Baden: Nomos. 
same Forum was to serve as the kingpin of the Citizen Alternative Parliament (GAP) of Bosnia, founded in August 1996, which went on to act as an umbrella for more than thirty different citizen initiatives across the nation. Hot on its heels, the Sarajevo Law Centre initiated a critical appraisal of the Dayton Agreement (the General Framework Agreement for Peace) which, at that time, everyone expected would soon be amended, rewritten or even abolished. When the first round of elections backed the power of the nationalist parties, opposition forces came together time and again in a shadow government, finally bringing 'Alliance for Change' to power in January 2001; though, sadly, it proved too fragile to last.

And here we close our list of the initiatives that we have seen being devised and established against all the odds by Bosnian activists. ${ }^{4}$

Alas, it is true that this potential for expertise and engagement on the part of local players was never of sufficient scale to compete with the power of those elites who were more corrupt than nationalist and who always knew how to play on the presence and support of an 'international community' that was at times as naïve as it was obliging.

Today, it is all too obvious that the political antics have run out of steam, hence the harsh criticism being levelled at the corruption of the political class as a whole, regardless of regional origin and allegiance. Even so, at a more fundamental level, it is the country's political architecture, negotiated in Dayton, that now finds itself in a state of collapse.

The 'international community' bears as much responsibility for this lamentable situation as does local politics. Not only has 'state corruption' been rejected, but with one clumsy initiative after the next (the last to date being the 2009 'Butmir package'), both Washington and Brussels have contributed to plunging the country into a situation of Kafkaesque dimensions. The process of integration into the European Union, which has been stagnant for a decade now, has exposed the sad reality of a total lack of political will on the part of Europe.

Those who are still pleading that change must come from outside the country, that it must be imposed, need to understand that democracy cannot be imposed. A more viable alternative is possible: one that resolutely empowers local stakeholders. It so happens that Bosnia has experience in such exercises, limited though they have been. In the wake of the creation of the Partnership Forum and Civic Forum in July 2001, by the then High Representative, these two new set-ups were able to kick-start the process of constitutional reform in the two entities. They concluded on 27 March 2002 in the Mrakovica-Sarajevo Agreement. In this negotiation process, which included experts and representatives from public interest groups, local players led the process, assisted by international experts. Likewise, further agreements have been reached since then, notably on military reform and the status of the District of Brčko. ${ }^{5}$

4 See Mient Jan Faber (Ed.) (1997) Dayton Continued in Bosnia Herzegovina (1) The Hague and Sarajevo: Helsinki Citizens' Assembly Publication Series 11.

5 See Christophe Solioz (2005) Turning Points in Post-War Bosnia Baden-Baden: Nomos (2nd edition 2007). 
Admittedly, what is now at stake is of considerable scale. A complete overhaul of the Dayton Agreement is unavoidable. It has become all too obvious by now that the reform of the overly complex constitution is essential, with the clear aim of putting in place a functional institutional architecture that will both strengthen the core capacities of the state and introduce a smart decentralisation process at the level of the regions that still have to be created. This, in turn, presupposes an end to the two-entity division of the country (both entities having proven to be as dysfunctional as they are weary), as well as the abolition of the ten cantons in a Federation that has been bankrupt since 2003.

The evidence is overwhelming, but Bosnian experts were already formulating streamlined political alternatives as far back as 1996. In contrast, the 'international community' has, thus far, refused to open what it terms a 'Pandora's box'. Displaying both misjudgement with respect to myth, and scorn with respect to politics, western diplomats gave up long before Bosnian politicians did.

Let us be more specific. Already back in 2007, when the disaster of the implementation of Dayton was looming on the horizon, Milan Kučan, the former President of Slovenia and one of the insiders in the break-up of Yugoslavia, had called for Dayton II to be drafted under the aegis of Bosnia and Herzegovina, Croatia and Serbia, as signatories, with international representatives as observers. ${ }^{6}$ This scenario has the merit of reaching beyond the alternatives of external imposition or internal solution. It sets out in a convincing manner a partnership that would assign a precise role for each party. It needs to be mentioned that the Sarajevo Foundation Public Law Centre (CJP) has been engaged since 2012 in a state-wide public debate with a view to drafting a new constitution. The expertise required is very much present in the country itself.

An alliance between local expertise and the new civic forces - such as the Citizens' Plenum in Tuzla - could very well develop into a public space that could challenge the clueless nomenklatura. Bosnia's social movement is emerging from a state of powerlessness and is opening up new possibilities.

That said, a different Bosnia needs a different Europe.

6 Milan Kučan (2007) 'A New View for the Balkans' in: Hannes Swoboda and Christophe Solioz (Eds.) Conflict and Renewal: Europe Transformed Baden-Baden: Nomos, pp. 217-223. 